\title{
Ranking quality in higher education: guiding or misleading?
}

\author{
Brita Bergseth, Peter Petocz and Madeleine Abrandt Dahlgren
}

Linköping University Post Print

Tweet

N.B.: When citing this work, cite the original article.

This is an electronic version of an article published in:

Brita Bergseth, Peter Petocz and Madeleine Abrandt Dahlgren, Ranking quality in higher education: guiding or misleading?, 2014, Quality in Higher Education, (20), 3, 330-347.

Quality in Higher Education is available online at informaworldTM:

http://dx.doi.org/10.1080/13538322.2014.976419

Copyright: Taylor \& Francis (Routledge): SSH Titles

http://www.routledge.com/

Postprint available at: Linköping University Electronic Press

http://urn.kb.se/resolve?urn=urn:nbn:se:liu:diva-122139 


\title{
Artikel I. Ranking quality in higher education: guiding or misleading?
}

\begin{abstract}
The study examines two different models of measuring, assessing and ranking quality in higher education. Do different systems of quality assessment lead to equivalent conclusions about the quality of education? This comparative study is based on the rankings of 24 Swedish higher education institutions. Two ranking actors have independently assessed the quality of these institutions during the same year. The analysis focuses on the concepts of quality on which the rankings are based, the choice of quality indicators, as well as methods, data sources and assessors. Although both actors base their rankings on the same overarching definition of quality, their conclusions do not correspond. The statistical method applied in this review, Bland-Altman analysis, indicates no significant agreement between the qualitative and quantitative measurements of quality in higher education. On the contrary, in several cases there are remarkable differences.
\end{abstract}

Keywords: quality assessment; ranking; higher education; medical and health care professions; qualitative and quantitative measurements

\section{Why ranking quality}

Worldwide, the expansion in higher education has never been greater. According to the UNESCO Institute for Statistics (UIS, 2012) 165 million students participated in academic studies in 2009, a five-fold increase since the 1970s. A growing trend is also seen in crossborder higher education, characterised by the movement of people, programmes and providers across national borders. At least 3.6 million students in 2010 were enrolled in tertiary education abroad. There has also been an increase in the number of higher education institutions, which currently number 22,000 according to the Webometrics Ranking of World Universities (2014) Meanwhile, the structure of universities grows more complex and the boundaries between different types of educational or research institutions are becoming more blurred (Rabow \& Rabow, 2005).

'The global expansion of access to higher education has increased demand for information on academic quality and has led to the development of university ranking systems or league tables in many countries of the world' (Dill \& Soo, 2005, p. 495). A predominant view is that ranking of academic quality is a global phenomenon that is here to stay (Bowden, 2000; Usher \& Savino, 2007; Kehm \& Stensaker, 2009). No doubt, league tables have gained public interest and credibility. As Longden (2011, p. 86) noted, 'the concept of trust becomes an integral part of the human condition'. Consequently, his thesis is that the compilers of university rankings have confidence in our trust and rely on us not to question their methodology and its various elements. Regardless of the ranking system applied, the actors may claim that their assessments and conclusions meet the demand for valuable and credible information on quality. Thus, the overarching purpose of providing good guidance to stakeholders in higher education, prospective students, politicians and the general public is achieved. Given that the ranking actors have these objectives in common, it should be useful to critically review and compare the systems of quality assessment and their outcomes.

This article reviews the models applied by, and analyses the results of, two different systems of ranking quality in higher education at 24 Swedish universities and university colleges in 2007. A comparison was made between the national quality assessments and rankings carried out by two independent actors, who both based their systems on international models. Finally, the validity, reliability and relevance of the ranking systems were compared. 


\section{The international scene}

'If university rankings are considered as consumer information, then everyone should have an interest in basing such guidance on valid and reliable data and methodology' (Stensaker \& Kehm, 2009, p. vii). Certainly, several attempts have been made to find valid measures of quality for relevant comparisons. So far, the most common international ranking concept applied is to assess and compare the quality of entire institutions and present the results as rankings, in so-called league tables. The starting point for these more systematically implemented rankings of universities and university colleges is generally considered to be 1983, when the U.S. News and World Report carried out a ranking of United States (US) universities (van Dyke, 2005; Salmi \& Saroyan, 2007). Since then, interest in rankings has grown considerably. The Academic Ranking of World Universities (ARWU) conducted by Shanghai Jiao Tong University and the Times Higher Education (THE) in the UK are generally considered to be among the most prominent global rankings (Rabow \& Rabow, 2005; Marginson \& van der Wende, 2007).

Information on quality in higher education is unanimously considered to be a legitimate requirement by the public (Hazelkorn, 2007; Salmi \& Saroyan, 2007; Usher \& Savino, 2007; Sadlak et al., 2008), in particular by

prospective students (Stensaker \& Kehm, 2009). In that sense, rankings have a broad purpose. Added to that, an underlying objective of rankings may also be to contribute to quality enhancement by stimulating higher education institutions to compete. Thus, the purposes of rankings, as well as ranking methods per se, can vary greatly among the wide range of actors in the 'ranking market'.

The range of commercial rankings is especially large in the US, where the best-known rankings are conducted by newspapers and magazines such as Atlantic Monthly, Business Week, the Financial Times, Money, U.S. News and World Report, the Wall Street Journal and Washington Monthly. Comparable ranking actors in other Anglo-Saxon countries are The Good Universities Guide in Australia, The Maclean's Guide to Canadian Universities in Canada and The Times Good University Guide and the Guardian University Guide in the UK (Dill \& Soo, 2005). These ranking actors and the kinds of system they apply have had a dominant influence on models and methods used for rankings of entire higher education institutions, often supplemented by rankings of specific education fields as well as subjects (Salmi \& Saroyan, 2007).

According to Dill and Soo $(2003$, p. 1) league tables are produced by commercial entities such as newspapers and magazines, professional societies, non-governmental organisations (NGOs), as well as governmental agencies. However, only a few rankings are based on results from specific quality assessments, evaluations or accreditation activities undertaken by the public sector. A notable exception is The Sunday Times University Guide, which ranks universities on the basis of information from government quality assessments (Almgren, 2009). Stensaker and Kehm (2009) asserted that most university rankings and guides are published by companies driven by commercial purposes. The publication of league tables in journals has proved to be a 'commercial success' (Dill \& Soo, 2005; Forneng et al., 2014; Harvey, 2008).

\section{The contemporary debate}

The increasing demand for higher education can be interpreted to mean that society has a great confidence in higher education institutions (Media Academy Confidence Barometer, 2012). The question is whether traditional rankings such as league tables deserve this confidence. Are rankings of quality in higher education guiding or misleading? In order to 'guide' prospective students and other stakeholders it is reasonable that rankings should be based on valid, reliable and relevant information. Higher education institutions could benefit 
from this information as a basis for their quality improvement efforts. Nevertheless, in the academic world internationally there is a widespread distrust of rankings of quality in higher education. 'Critiques of rankings come from an array of sources and are based on methodological, pragmatic, moral and philosophical concerns' (Harvey, 2008, p. 190).

Regardless of the criticism, Dill (2009) noted that it is possible to compile valid league tables with a positive influence on the educational quality of academic programmes. He argued that assessments based on the definition of a quality notion determine the choice of assessment model, quality indicators, method of analysis, selection of data and analysts. Despite the fact that several international researchers and ranking debaters agree on this, an internationally accepted definition of what constitutes quality in higher education is still lacking (Dill \& Soo, 2005; Usher \& Savino, 2006; Harvey, 2008). Even if ranking actors do not explicitly accept any particular quality definition, it is possible to interpret an indirect definition in the very model of ranking. Usher and Savino (2007) noted that different ranking actors apply different quality indicators. In fact, the choice of indicators and the weighting of them indirectly specify the notion of quality. Consequently, notions of quality may differ significantly. Usher and Medow (2009, p.12) concluded, "the notion of "quality" in higher education is clearly a very malleable one'. In any case, a common, universal definition of quality in higher education is presumed for rankings to win legitimacy in the academic world (Harvey, 2008) and to serve as a sound basis of guidance for prospective students when choosing higher education (Marginson \& van der Wende, 2007).

\section{The Swedish scene}

Despite the international criticism concerning the credibility of quality rankings, new ranking actors have also emerged in Sweden. Academic institutions can no longer escape being assessed and compared with others. Since 2000, Swedish higher education institutions have been systematically assessed and ranked at the national level by four main actors. The first actor is the independent authority, the former Swedish National Agency for Higher Education (NAHE), now the Swedish Higher Education Authority; by government assignment it evaluates the entire range of subjects and education programmes provided at all institutions (Government Bill, 1999/ 2000). The second is Urank, a private commercial association (Forneng et al., 2014). Since 2007, Urank has published national rankings of the majority of Swedish universities and higher education institutions in the media. A third actor, the Sydsvenska Industri- och Handelskammaren [the Southern Swedish Chamber of Industry and Commerce], assessed and ranked quality in higher education and research primarily targeted at industry and commerce from 2006 to 2009. The fourth actor is the Svenskt Näringsliv [Confederation of Swedish Enterprise] that since 2008 has presented rankings of higher education institutions, covering a large number of subject areas, on an interactive website in cooperation with the private sector, (Svenskt Näringsliv, 2014).

The question that is raised in this paper is how to interpret and compare the outcomes of various rankings. Basically, the premise of a relevant comparison is that the institutions are the same and that the quality assessments and rankings are carried out simultaneously and independently. Furthermore, a common overarching definition of quality contributes to the validity of a review. Added to that, an application of systems for assessments and rankings referring to worldwide models contributes to international relevance. For the purpose of this study, a comparison between the National Agency evaluation and Urank ranking is considered to be adequate in order to explore whether the conclusions concerning quality are equivalent, that is, whether they confirm each other or not. 


\section{The design of the empirical study}

The study was based on the results from the national rankings of academic education undertaken independently in the same year at 24 institutions. The first of these is the evaluation of a sample of degree programmes conducted by the National Agency (Bergseth, 2007); the results of this evaluation can be expressed as ranks. The second is the ranking of a sample of entire units of institutions conducted by Urank (2007). The two cases were then compared using the qualitative content analysis method of Usher and Savino (2006). Subsequently, a quantitative statistical analysis of the ranking outcomes was made according to Bland and Altman (1986). The following is a description of the two systems of quality assessment.

\section{The National Agency aim and model of ranking}

One of the main aims of the systematic monitoring of quality undertaken by the National Agency was to provide prospective students with readily available information for comparing and selecting programmes. First and foremost, the purpose was to monitor compliance with the Higher Education Act (1992; NAHE, 2001), which requires that higher education be based on scientific principles and proven experience and that there is a close link between research and education. Moreover, assessments in accordance with this notion of quality comprise a review of the entitlement to award degrees. As an independent authority, the Agency has the right to issue or withdraw the entitlement to award a degree, depending on whether or not the education provided meets the standards. In order to attain these objectives, the Agency applied a qualitative methodology for assessment and ranking consistent with the Standards and Guidelines for Quality Assurance in the European Higher Education Area (ENQA, 2005; Franke \& Nitzler, 2008). Responsibility for judging quality lay with the external panels of experts representing academics, professionals and students from the area under evaluation. This is in compliance with a peer-review model, except for the inclusion of students (Askling, 2007). The assessment process covered four stages: self-evaluation; local visit; report; feedback and follow-up. In the course of on-site visits, views were obtained from senior university officers, programme co-ordinators, teachers and students concerned, as well as employers and clinical supervisors at the local and regional levels. It should be noted that this evaluation model has now been replaced by a new system focusing on academic results.

\section{Quality indicators applied by the National Agency}

The primary assignment of the panels of assessors is to judge quality according to the general academic requirements under the law and regulations. Higher education should be based on scientific principles and proven experience and research should be closely linked to education. The indicators of quality are interpreted from general and specific aspects of the education programmes (Table 1). Each group of aspects was assessed using a four-point scale (1-4), where the lowest level (1) indicated that the standard was unsatisfactory. One of the key measures of the educational result is the assessment of the constructive alignment (Biggs, 2003). Eventually, the conclusions on quality formed the basis for the National Agency's decision on the approval or non-approval of the education programme as a whole.

\section{The Urank aim and model of ranking}

The second concept of quality assessments is the ranking by Urank in 2007. Forneng et al. (2014) stated that their aim is to highlight quality in higher education by annual rankings based on surveys and comparisons of quality-assured quantitative data. The information on quality in education is targeted at prospective students, the labour market, the public and other stakeholders in higher education. In common with the National Agency, the notion of quality 
embodied in the Higher Education Act (1992) is the basis for the choice of quality criteria and indicators. Urank emphasises that the assessments relate to undergraduate education, not to research or postgraduate education. However, considering that research resources constitute the prerequisites for providing a research-based education, these aspects are included in the basic quality criteria (Forneng et al., 2014).

The design of the quality ranking applied by Urank is based mainly on the methodology of Maclean's Guide to Canadian Universities (Maclean's) ranking in Canada. This concept is cited as the primary model, taking into account its design, including quality indicators and their weighting. One of the reasons for the choice of model was Maclean's long-term experience of gathering the best numerical data to compare the quality of Canadian

\section{Table 1. National Agency ranking 2007: General and specific aspects and criteria of quality in medical and health care education programmes}

\begin{tabular}{|c|c|c|}
\hline & Criterion & Scale \\
\hline \multicolumn{3}{|l|}{ General aspect } \\
\hline Prerequisites & $\begin{array}{l}\text { Decision-making structure, budget and financial management, } \\
\text { stability and long-term planning, teacher competence, research } \\
\text { activity and skills development within the programme, teacher } \\
\text { competence in clinical education, research activity and skills } \\
\text { development programmes, student admissions and selection } \\
\text { structure and organisation, availability of seats in the clinical } \\
\text { training, access to tutors. }\end{array}$ & $1-4$ \\
\hline Implementation & $\begin{array}{l}\text { Introduction to training, theoretical training, spectrum of } \\
\text { subjects, advanced study, teaching and tutoring format, } \\
\text { examination format, clinical training, advanced levels, ways of } \\
\text { teaching and tutoring, examination format, integration between } \\
\text { theoretical and clinical training, long-term management of } \\
\text { major change, evaluation. }\end{array}$ & $1-4$ \\
\hline Results & $\begin{array}{l}\text { Quality of degree projects, examination results, student } \\
\text { completion, follow up, pedagogic projects published the last } \\
\text { three years, students' knowledge and skills in relation to the } \\
\text { general goals of higher education, the links between research } \\
\text { and education and the students' capacity for critical and } \\
\text { independent thinking. }\end{array}$ & $1-4$ \\
\hline \multicolumn{3}{|l|}{ Specific aspect } \\
\hline $\begin{array}{l}\text { Clinical } \\
\text { placement } \\
\text { education }\end{array}$ & $\begin{array}{l}\text { How the target of the clinical placement training is formulated } \\
\text { and reflected in teaching; how the university ensures that the } \\
\text { goals of the practical training are achieved; how the institution } \\
\text { has been able to manage the organisational changes in } \\
\text { healthcare over the past five years. }\end{array}$ & $1-4$ \\
\hline
\end{tabular}

institutions. In support of the methodological approach, Urank also refers to the set of principles of quality and good practice in rankings according to the International Ranking Expert Group (IREG) and the Berlin Principles on Ranking of Higher Education Institution (IREG, 2006; Hägg \& Wedlin, 2013).

Since 2007, when the Urank association appeared for the first time, its ranking lists have been published on its own website, in magazines and the main national Swedish newspapers. Urank presents itself as an independent association. However, with regard to the publications 
in commercial media its independent position as a ranking actor might be questioned (Marginson \& van der Wende, 2007).

\section{Quality indicators applied by Urank}

Like most ranking designers, Urank has to rely on available numerical statistics. That is, the selection of indicators as well as the number of institutions included in the ranking is determined by the availability of data (Dill \& Soo, 2005; Usher \& Savino, 2006). The quantitative statistical indicators applied are based on quality-assured data from the official statistics of the National Agency for Higher Education (HSV, 2007b). Added to that, statistics concerning library resources are obtained from Statistics Sweden [Statistiska Centralbyrån] and student assessments from the Agency Student Mirror [Studentspegeln] survey (HSV, 2007a). Since the inception of the rankings, two of the six original criteria have been replaced (Table 2).

Table 2. Urank ranking 2007: Criteria, indicators and weighting

\begin{tabular}{|c|c|c|c|}
\hline Criterion & $\begin{array}{l}\text { Weighting } \\
\text { of } \\
\text { criterion }\end{array}$ & Indicators within each criterion & $\begin{array}{l}\text { Weighting } \\
\text { of } \\
\text { indicators }\end{array}$ \\
\hline \multirow[t]{5}{*}{ Students } & \multirow[t]{5}{*}{0.2} & First-hand applicants & 0.33 \\
\hline & & New students from outside the county & 0.13 \\
\hline & & $\begin{array}{l}\text { Students from outside the county taking a } \\
\text { degree }\end{array}$ & 0.13 \\
\hline & & Students studying the second year & 0.2 \\
\hline & & $\begin{array}{l}\text { New students taken a degree within six } \\
\text { years }\end{array}$ & 0.2 \\
\hline \multirow[t]{2}{*}{ Teachers } & \multirow[t]{2}{*}{0.2} & $\begin{array}{l}\text { Proportion of teachers who have defended } \\
\text { a thesis }\end{array}$ & 0.5 \\
\hline & & Ratio of professors to teachers & 0.5 \\
\hline \multirow{4}{*}{$\begin{array}{l}\text { Undergraduate } \\
\text { education }\end{array}$} & \multirow[t]{4}{*}{0.2} & Students per teacher, weighted & 0.25 \\
\hline & & Level of achievement, weighted & 0.25 \\
\hline & & Mobility factor & 0.25 \\
\hline & & $\begin{array}{l}\text { Establishment in the labour market, } \\
\text { weighted }\end{array}$ & 0.25 \\
\hline \multirow{5}{*}{$\begin{array}{l}\text { Research and } \\
\text { post-graduate } \\
\text { education }\end{array}$} & \multirow[t]{5}{*}{0.2} & $\begin{array}{l}\text { Research grants per teacher defending a } \\
\text { doctoral thesis }\end{array}$ & 0.2 \\
\hline & & $\begin{array}{l}\text { Ration of research to the institution's total } \\
\text { costs }\end{array}$ & 0.2 \\
\hline & & $\begin{array}{l}\text { Research funding subject to competition in } \\
\text { comparison with total research funding }\end{array}$ & 0.2 \\
\hline & & $\begin{array}{l}\text { Students who transfer to post-graduate } \\
\text { studies, weighted }\end{array}$ & 0.2 \\
\hline & & Defences of doctoral theses per professor & 0.2 \\
\hline Libraries & 0.1 & & 0.1 \\
\hline $\begin{array}{l}\text { Student } \\
\text { assessments }\end{array}$ & 0.1 & & 0.1 \\
\hline
\end{tabular}

\section{Comparative analysis of the two cases}




\section{The comparative qualitative analysis}

For the analysis of the similarities and differences between the National Agency and the Urank ranking systems the Usher and Savino model, a survey of the characteristics of international (global and national) ranking systems published in 2006, was applied. The authors summarise, as characteristics of 'league tables', the parameters that are most frequently used in university rankings in seven sets of quality indicators. The sets into which Usher and Savino (2006) have divided the parameters are as follows.

Beginning characteristics. These represent the characteristics, attributes and abilities of incoming students as they start their programmes.

Learning inputs: staff. Not just the number of staff but also the way in which they are deployed to teach and the learning environment they create, as measured by the amount of contact time students have with their teachers and the kinds of examinations they face.

Learning inputs: resources. These are both financial and material, available to students and academic staff for educational ends.

Learning outputs. These represent the 'skill sets' or other attributes of graduates that result from their educational experience, such as critical thinking, analytic reasoning and technical knowledge. They also include records relating to retention and completion.

Final outcomes. These represent the ultimate ends to which the educational system may contribute, including not only such traditional measures as employment rates and incomes but also any other outcome deemed to be important to individuals and society, such as job satisfaction, an appreciation of the finer things in life and being a 'good citizen'.

Research. This is represented by bibliometric citations in various publication indices, the number of publications, research awards and research budgets.

Reputation. This represents reputation among employers, academic peers and students.

The comparison between the National Agency and Urank ranking concepts, according to the Usher and Savino model (2006), showed a pattern of differences (Table 3).

Usher and Savino (2006) also stressed the type of data sources as essential variables when comparing different ranking models. Therefore, their indicators, survey data and data from third parties were added to the comparison (Table 4).

In order to deepen and broaden the comparison, the model was complemented (Table 5) by three characteristics of ranking systems concerning quality definitions (Dill \& Soo, 2005; Usher \& Savino, 2006; Harvey, 2008; Stensaker \& Kehm, 2009), methods of analysis and assessors (Askling, 2007).

Table 3. Characteristics of league tables (Usher \& Savino, 2006): The National Agency and Urank ranking comparison

\begin{tabular}{lll}
\hline Quality indicators & National Agency & Urank \\
\hline Beginning characteristics & No & Yes \\
$\begin{array}{l}\text { Learning inputs } \\
\text { - staff }\end{array}$ & $\begin{array}{l}\text { Quality and quantity of staff } \\
\text { employed for teaching in } \\
\text { the education programme }\end{array}$ & $\begin{array}{l}\text { Quality and quantity of } \\
\text { staff employed at the } \\
\text { institution as a whole }\end{array}$ \\
$\begin{array}{l}\text { Learning inputs } \\
\text { - resources }\end{array}$ & Yes & Yes
\end{tabular}




\begin{tabular}{lll} 
Learning outputs & Yes & Yes \\
Final outcomes & No & No \\
Research & $\begin{array}{l}\text { Research and education } \\
\text { connection }\end{array}$ & Research performance \\
Reputation & No & No \\
\hline
\end{tabular}

Table 4. Indicators by Type of Data Source (Usher \& Savino, 2006): The National Agency and Urank ranking comparison

\begin{tabular}{lll}
\hline Data source & National Agency & Urank \\
\hline Survey data & $\begin{array}{l}\text { Students', teachers', employers' } \\
\text { and clinical supervisors' } \\
\text { opinions, interviews at local site } \\
\text { visits }\end{array}$ & $\begin{array}{l}\text { Students' opinion, } \\
\text { questionnaire survey at } \\
\text { national level }\end{array}$ \\
$\begin{array}{l}\text { Data from } \\
\text { third parties }\end{array}$ & $\begin{array}{l}\text { Quality-assessed official data } \\
\text { at national, institutional and } \\
\text { programme levels }\end{array}$ & $\begin{array}{l}\text { Quality-assessed official data } \\
\text { at national level and } \\
\text { institutional levels }\end{array}$ \\
\hline
\end{tabular}

Table 5. Additional Characteristics: The National Agency and Urank ranking comparison

\begin{tabular}{lll}
\hline Characteristics & National Agency & Urank \\
\hline $\begin{array}{l}\text { Quality } \\
\text { definition }\end{array}$ & $\begin{array}{l}\text { Higher education Act and } \\
\text { Ordinance }\end{array}$ & $\begin{array}{l}\text { Higher education Act and } \\
\text { Ordinance }\end{array}$ \\
$\begin{array}{l}\text { Method of } \\
\text { analysis }\end{array}$ & Qualitative & Quantitative \\
Assessors & $\begin{array}{l}\text { Non-commercial } \\
\text { Independent assessment } \\
\text { groups, teachers and students }\end{array}$ & $\begin{array}{l}\text { Commercial } \\
\text { Independent private } \\
\text { ranking actors }\end{array}$ \\
\hline
\end{tabular}

\section{Differences and similarities of qualitative variables}

In the international comparison of characteristics and indicators according to Usher and Savino (2006) the Swedish actors show relatively minor differences. Except for differences regarding assessments of education programmes versus assessments of entire institutions, the concepts differ with regard to only two of the seven sets of quality indicators. First, only Urank reported the students' 'beginning characteristics' as a quality indicator. Second, the National Agency assessed the quality indicator for research as the link between research and education (Biggs, 2003), while Urank assessed the institutional resources for research and education separately. Furthermore, the concepts differ by type of data sources in the sense that the National Agency uses mixed types of data collection, interviews and official quality- 
assessed data from third parties. In comparison, Urank uses official quantitative data from questionnaires as well as official quality assessed data. The additional characteristics chosen for this comparative study indicate that the National Agency and Urank base their assessments on a common overarching notion of quality. However, there are differences concerning the choice of method for data analysis. The National Agency applies a qualitative method for assessing quality, unlike Urank that, due to the statistical data sources, has to apply a quantitative method to assess the quality of higher education.

\section{The comparative quantitative analysis}

The National Agency analysis was based on a sample of assessments of 118 education programmes that offer academic degrees for the following professions: audiologist, biomedical scientist, dental hygienist, dental technician, medical physicist, midwife, generalcare nurse, occupational therapist, optician, orthopaedic engineer, physiotherapist, radiographer, specialist nurse and speech therapist. The quality of the programmes is reported as the sum score of the expert judgements according to four groups of indicators and each group is assessed on an ordinal scale 1-4. Each institution is given a mean score and ranked (Table 6).

By comparison, the ranking by Urank was based on parametric data analysed according to a normal distribution (Table 6).

Table 6. The 2007 National Agency (NA) and Urank assessments of quality in higher education at 24 institutions

\begin{tabular}{|c|c|c|c|c|}
\hline $\begin{array}{l}\text { Higher education } \\
\text { institution }(n=24)\end{array}$ & NA (mean) & NA rank & Urank (SD) & Urank rank \\
\hline $\begin{array}{l}\text { Blekinge Institute of } \\
\text { Technology }\end{array}$ & 5 & 22.5 & -038 & 20 \\
\hline Borås University College & 8 & 8.5 & -0.03 & 10 \\
\hline Dalarna University College & 6.75 & 15.5 & -0.36 & 19 \\
\hline Gävle University College & 6 & 21 & -0.45 & 23.5 \\
\hline Göteborg University & 8.5 & 4.5 & 0.26 & 5 \\
\hline Halmstad University College & 6.5 & 19 & -0.33 & 16.5 \\
\hline Jönköping University College & 8.43 & 6 & -0.26 & 14 \\
\hline Kalmar University College & 8.2 & 7 & -0.41 & 22 \\
\hline Karlstad University & 7.5 & 10.5 & -0.15 & 12 \\
\hline Karolinska Institute & 8 & 8.5 & 0.82 & 1 \\
\hline Kristianstad University College & 7 & 13.5 & -0.27 & 15 \\
\hline Linköping University & 7.5 & 10.5 & 0.27 & 4 \\
\hline Luleå University of Technology & 6.6 & 18 & 0.08 & 8 \\
\hline Lund University & 9.44 & 2 & 0.5 & 2 \\
\hline Malmö University College & 8.75 & 3 & -0.23 & 13 \\
\hline Mid-Sweden University & 8.5 & 4.5 & -0.4 & 21 \\
\hline Mälardalen University College & 6.75 & 15.5 & -0.33 & 16.5 \\
\hline Skövde University College & 4.67 & 24 & -0.45 & 23.5 \\
\hline Stockholm University & 10 & 1 & 0.23 & 6 \\
\hline Umeå University & 7.27 & 12 & 0.14 & 7 \\
\hline University West & 5 & 22.5 & -0.34 & 18 \\
\hline Uppsala University & 7 & 13.5 & 0.44 & 3 \\
\hline
\end{tabular}




\begin{tabular}{lrrrr} 
Växjö University & 6.67 & 17 & -0.08 & 11 \\
Örebro University & 6.33 & 20 & 0.02 & 9 \\
\hline
\end{tabular}

The purpose of using the Bland-Altman method of analysis was to assess the level of agreement between the two different methods of measurements and to determine whether these methods could be used interchangeably. The obvious approach might be to rank the cases and find the correlation coefficient (r) between the results of the two measurements as an indicator of agreement. However, a high correlation does not necessarily mean that the two methods agree (and in this case the correlation is a modest value of 0.46). Bland and Altman assert that neither the correlation coefficient nor techniques such as regression analysis are appropriate. The alternative method of analysis is to plot the difference scores of measurements against the average of each subject on a graph (Figure 1). This method can also include an estimation of confidence intervals for the bias and limits of agreements (Myles \& Cui, 2007).

\section{No significant agreement between measurements and rank}

The Bland-Altman analysis indicated no significant agreement between the National Agency and Urank methods of measuring and the ranking of quality in higher education at 24 institutions. A random scatter of points on this plot indicated no systematic bias between the two methods; and 'limits of agreement' between the two methods could be found from the standard deviation of the difference values. The difference between the two methods ranged from -16.5 to +11.0 and the $95 \%$ 'limits of agreement' were between -14.3 and +14.3 on the numerical ranking. This wide range of difference values indicates that the methods do not agree sufficiently to be interchangeable. 


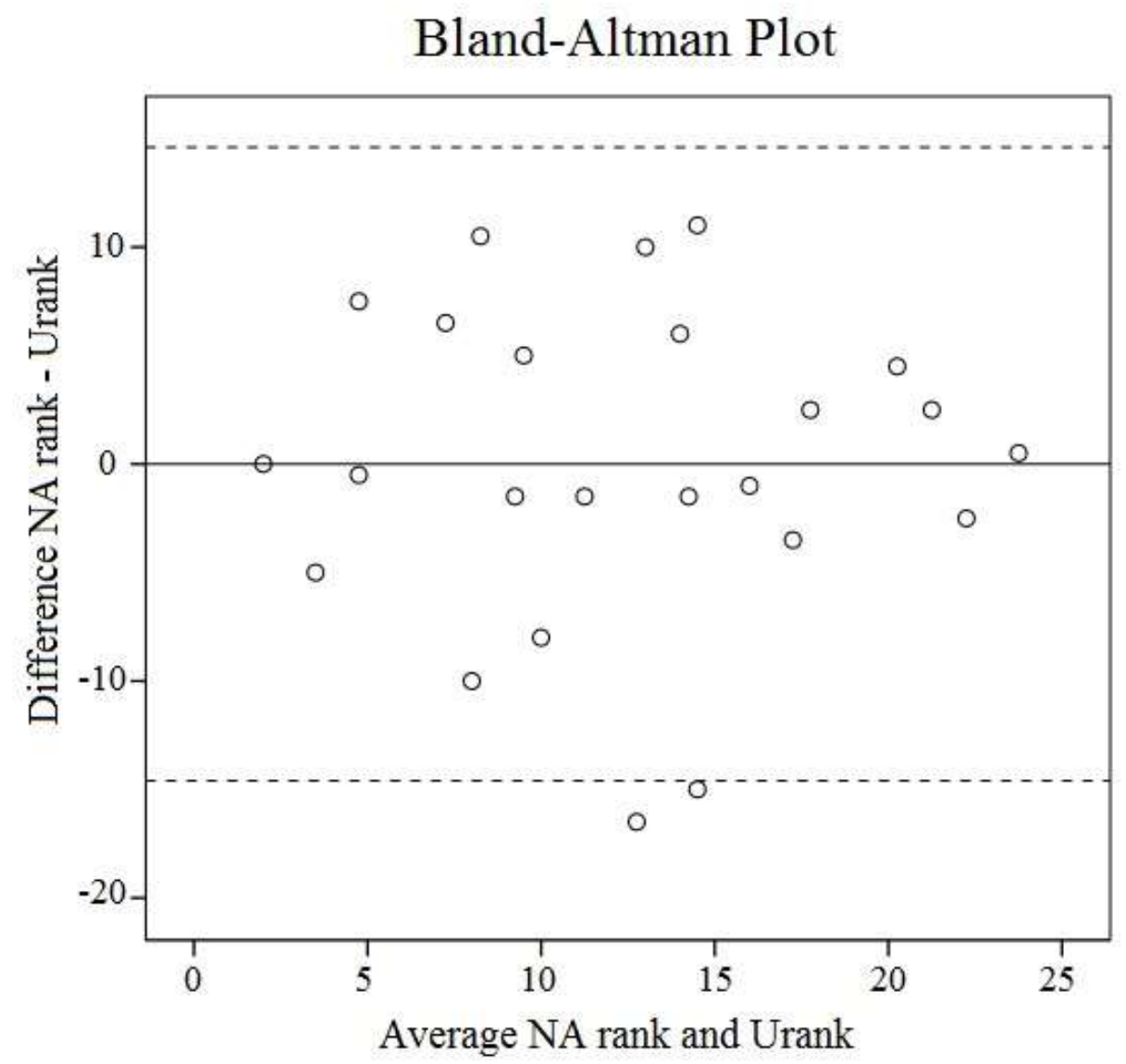

Figure A. Bland-Altman plot analysis of differences and averages of the outcomes of the National Agency (NA) and Urank rankings of 24 institutions (showing 'limits of agreement' from -14.6 to +14.6 )

\section{The differences are remarkable}

Despite the fact that the National Agency for Higher Education and the Urank association based their rankings on the same overarching definition of quality, the conclusions on quality agree only to a level consistent with chance. The statistical method applied in this review, the Bland-Altman analysis (1986), indicates no significant agreement between the measurements of assessing and ranking quality in higher education. In several cases the differences were remarkable. That is, the Urank rankings did not predict the outcomes of the National Agency quality assessments of the sample of educational programmes. Correspondingly, the National Agency quality assessments did not confirm the rankings carried out by Urank.

Thus, the outcomes of the two independent rankings of the 24 institutions carried out during the fiscal year 2006 show essentially independent results. Nevertheless, each of the ranking actors, the National Agency and Urank claim that their assessments and rankings provide valid measures of quality. Both of them refer to international models and methods for quality assessment. The public authority, the National Agency, for its part, used a modified research-based model for evaluation, harmonised to ENQA (2005). The private commercial association, Urank, on the other hand, chose to apply an international ranking model according to Maclean's Guide to Canadian Universities (Maclean's, 2007).

Additionally, there is another major difference between the assessments. The National Agency ranked the quality of a sample of specific education programmes within a defined 
area, in this case medicine and healthcare, provided at some institutions. Urank summarised the assessment of the overall quality of education at universities and university colleges and presented its results according to international practice in the form of a ranking list, a so called league table. Nevertheless, the two assessment and ranking models have several factors in common that contribute to proving the relevance of the comparison. Beyond the fact that the institutions included in the study are the same, there are correspondences on some additional essential points.

To evaluate, rate and provide information on the quality of academic education is onerous. The National Agency assignment is particularly onerous. Based on the quality assessments, the Agency has the right to provide, accredit or revoke entitlement to award a qualification concerning a subject or a programme. Sanctions of this type have been used in some cases within the field of medicine and health-care education. The reason is that compromises or uncertainty concerning quality are unacceptable for courses leading to certification directly after graduation. Contrary to Urank, which applies weightings of various criteria and indicators, the National Agency places equal demands on all institutions concerning the quality of educational results, irrespective of the conditions regarding the availability of teachers, research resources and students' beginning characteristics. The focus on educational results was confirmed by the final outcome of the National Agency follow-up evaluation one year later. In 2008, the Agency withdrew in total six rights to award degrees for different professions in medicine and health care at five higher education institutions, four of which were universities.

Urank, in turn, is responsible to the public, considering the powerful impact that commercially successful ranking publications may have. Still, it is unclear to what extent publication of rankings has an impact on student choices and the governance of higher education institutions' development. A potential influence cannot be excluded (Stensaker \& Kehm, 2009). Systematic errors are unfortunately embedded in this model of ranking. Usher and Medow (2009) pointed to the weakness of the underlying assumption in the ranking of universities that 'one size fits all'. No doubt it is risky to draw conclusions on the quality of education in specific subjects and programmes on the basis of accumulated data from the academic diversity within an institution and vice versa.

Under all conditions, demands for valid and reliable quality assessments and rankings are justified. Review and criticism of the ranking systems cannot be ignored. The Usher and Savino (2006) model of analysing ranking systems facilitates systematic comparisons of national as well as international models of quality assessment. The decisive question concerns the notion of quality. Finnie and Usher (2005), Usher and Savino (2006) and Usher and Medow (2009) argued that the ranking actors in effect specify their interpretation of the quality definition by their choice of quality indicators and data sources and the weightings applied to the various indicators. In an attempt to clarify the pattern of assessment systems, three supplementary characteristics are defined in this comparative study: quality definition (Dill \& Soo, 2005; Usher \& Savino, 2006; Harvey, 2008; Stensaker \& Kehm, 2009), method of analysis (Dill \& Soo, 2005) and quality assessors (Askling, 2007).

The conclusion is that the National Agency and Urank base their assessments on the overall quality definition as it is expressed in the Act governing the higher education sector. Thus, the difference in the outcomes cannot be explained by any differences in the notion of quality; nor can it be explained by any major differences between these two ranking actors according to the international comparison with the Usher and Savino (2006) model. Instead, the explanation may be sought in the different methods applied; that is, the qualitative or the quantitative method applied to assess quality in higher education. Another explanation for the varying findings on quality might be related to the assessors themselves. 
One of the factors likely to determine the different outcomes of the assessments is the choice of method for analysing data. While the National Agency applies a qualitative method, Urank uses a quantitative method for assessing quality. The National Agency bases its qualitative analysis on newly collected quality data as well as official statistics. Urank, on the other hand, relies exclusively on quantitative data, selecting a sample of the avail

able official statistics and subsequently weighting a number of related parameters. The methods of analysis might be interpreted as if the actors have separate notions of quality. Even though they share a general definition of quality, this study shows that they do not share to the same extent each other's views on how and what factors constitute quality. The choice of measurement methods may have one of several explanations. Some of these refer to measurements of quality based on a sample of data from statistical annual reports and parameters that are separately assessed, accumulated and weighted. Others refer to measurements designed to review how different quality factors interact and are aligned (Biggs, 2003).

Depending on which model and method of measurement are applied, the quality assessments demand different expert competences. Askling (2007) argues that the international concept of reviewing and assessing the quality of research within a specific academic discipline has gained legitimacy through the model of peer assessments. However, the complexity of education and multidisciplinary education programmes requires complementary assessment models and methods of measurement. So far, no internationally established model for review and assessment of higher education has achieved academic recognition and legitimacy equivalent to the assessment of research.

\section{Summary}

It could have been expected that the ranking systems reviewed would be reasonably comparable. Nonetheless, the results show they are not. One of the reasons may be due to the difference between ranking quality in a sample of education programmes in medicine and health care versus ranking quality in undergraduate education at an entire institution. Another reason may be in the subtleties of how the definition of quality is operationalised, even though the underlying definitions are essentially the same. An additional issue is whether alternative samples of programmes would show greater consistency with the rankings of institutions. However, the mere fact that there are inconsistencies in the outcomes of quality assessments raises concerns regarding the credibility of the rankings for information purposes. Thus, this study highlights a plurality of methodological as well as ethical issues in the search for valid and reliable assessment models and methods of measuring quality in higher education.

\section{References}

Almgren, E., 2009, Ranking of Universities and Higher Education Institutions for

Student Information Purposes? (Stockholm, Högskoleverket).

Askling, B., 2007, Om sakkunskap och expertis i nationella utvärderingar

och Kvalitetsbedömningar [Knowledge and expertise in national evaluation and quality assessments]. (Göteborg, Göteborgs universitet).

Bergseth, B., 2007, Utvärdering av grundutbildningar i medicin och vård vid svenska universitet och högskolor [Evaluation of education programmes in medical and health care at Swedish universities and colleges] (Stockholm, Högskoleverket).

Biggs, J., 2003, Teaching for Quality Learning at University (Buckingham, Society for Research into Higher Education \& Open University Press).

Bland, J.M. \& Altman, D.G., 1986, 'Statistical methods for assessing agreement between two methods of clinical measurement', The Lancet, 327(8476), pp. 307-10.

Bowden, R., 2000, 'Fantasy higher education: university and college league 
tables', Quality in Higher Education, 6(1), pp. 41-60.

Dill, D. \& Soo, M., 2003, A League Table of League Tables: A Cross National Analysis of University Ranking Systems, Research Program on Public Policy for Academic Quality (PPAQ) (Dublin, INQAAHE).

Dill, D. \& Soo, M., 2005, 'Academic quality, league tables, and public policy: a crossnational analysis of university ranking systems', Higher Education, 49(4), pp. 495-533.

European Association for Quality Assurance in Higher Education (ENQA), 2005, Standards and Guidelines For Quality Assurance in the European Higher Education Area (Helsinki, ENQA).

Finnie, R. \& Usher, A., 2005, Measuring the Quality of Post-secondary Education: Concepts, current practices and a strategic plan, Canadian Policy Rese Arch Group (CPRN) Research Paper W|28, April 2005.

Forneng, S., Lind, I. \& Nybom, T., (Urank) 2014, Sveriges universitetsranking, 2007. Available at http://www.urank.se/artiklar/?news_id=172\&news_page $=1$ (accessed 15 September 2014).

Franke, S. \& Nitzler, R., 2008, Att kvalitetssäkra högre utbildning - en utvecklande resa från Umeå till Bologna [Quality assurance of higher education - a developmental travel from Umeå to Bologna] (Pozkal, Studentlitteratur AB).

Government Bill 1999/2000:28, (Stockholm, Swedish Government).

Harvey, L., 2008, 'Editorial. Rankings of higher education institutions: a critical review', Quality in Higher Education, 14(3), pp. 187-207.

Hazelkorn, E., 2007, 'The impact of league tables and ranking systems on higher education decision making', Higher Education Management and Policy, OECD, 19(2), pp. $87-110$.

Hägg, I. \& Wedlin, L., 2013, 'Standards for quality? A critical appraisal of The Berlin principles for international rankings of universities', Quality in Higher Education, 19(3), pp. 326-42.

Högskoleverket (HSV), 2007a, Studentspegeln (Stockholm, Högskoleverket).

Högskoleverket (HSV), 2007b, Universitet \& högskolor [Universities \& Colleges] (Stockholm, Högskoleverket).

Högskoleverket (HSV), 2008, Besluts PM över uppföljning av ifrågasatta examensrätter inom vård och medicin [Decision PM of monitoring contested programmes in medical and health care] (Stockholm, Högskoleverket).

International Rankings Expert Group (IREG), 2006, Berlin Principles on Rankings of Higher Education Institutions. Available at http://www.iregobservatory.org/ in dex.php?option=com_content\&task=view\&id=41\&Itemid=48 (accessed 15 September 2014).

Kehm, B.M. \& Stensaker, B. (Eds.), 2009, University Rankings, Diversity, and the New Landscape of Higher Education (Rotterdam, Sence).

Longden, B., 2011, 'Methodological issues of university rankings', in Shin, J.C., Toutkoushian, R.K. \& Teichler, U. (Eds.) University Rankings Theoretical Basis, Methodology and Impacts on Global Higher Education (Dordrecht, Springer).

Maclean's, 2007, University Rankings. Available at http://www.macleans.ca/education/unirankings/our-17th-annual-rankings (accessed 15 September 2014).

Marginson, S. \& van der Wende, M., 2007, 'To rank or to be ranked: the impact of global rankings in higher education', Journal of Studies in International Education 11(3-4), pp. 306-29.

Media Academy Confidence Barometer, 2012. Available at http://medieakademien.se/wpcontent/uploads/2014/03/2012. MedieAkedemins_Fortroendebarometer.pdf 
(accessed 15 September 2014).

Myles, P.S. \& Cui, J., 2007, 'Using the Bland-Altman method to measure agreement with repeated measures', British Journal of Anaesthesia, 99(3), pp. 309-11.

National Agency for Higher Education (NAHE), 2001, National Review of Subjects and Programmes in Sweden (Stockholm, Högskoleverket).

Rabow, I. \& Rabow, H., 2005, Rankning av Universitet - en kort översikt [Ranking of Universities - a brief outline] (Lund, Lunds Universitet).

Academic quality, league tables, and public policy: a cross-national analysis of university ranking systems', Higher Education, 49(4), pp. 495-533.

Sadlak, J., Merisotis, J. \& Liu, N.C., 2008, 'University rankings: seeking prestige, raising visibility and embedding quality - the editors' views', Higher Education in Europe, 33(2/3), pp. 195-99.

Salmi, J. \& Saroyan, A., 2007, 'League tables as policy instruments: uses and misuses', Higher Education Management and Policy, 19(2), pp. 31-68.

Svenskt Näringsliv [Confederation of Swedish Enterprise], 2014. Available at http://www.svensktnaringsliv.se/sokresultat/?q=högskolekvalitet (accessed 15 September 2014).

Swedish Higher Education Act, 1992:1434, (Stockholm, Swedish Government).

United Nations Educational, Scientific and Cultural Organization (UNESCO) \& Institute for Statistics (UIS), 2012. Available at http://www.uis.unesco.org/Education/Pages/tertiary-education.aspx (accessed 15 September 2014)

Usher, A. \& Medow, 2009, 'A global survey of university rankings and league tables', in Kehm, B.M. \& Stensaker, B., (Eds.) University Rankings, Diversity, and the New Landscape of Higher Education, (Rotterdam, Sense).

Usher, A. \& Savino, M., 2006, A World of Difference: A global survey of University league tables (Toronto, Educational Policy Institute).

Usher, A. \& Savino, M., 2007, 'A global survey of university ranking and League tables', Higher Education in Europe, 30(2), pp. 103-25.

van Dyke, N., 2005, 'Twenty years of university report cards', Higher Education in Europe, 30(2), pp. 103-25.

Webometrics Ranking of World Universities, 2014. Available at http://www.webometrics.info/en/node/52 (accessed 15 September 2014). 